This document has been downloaded from

TamPub - The Institutional Repository of University of Tampere

Post-print

The permanent address of the publication is http://urn.fi/URN:NBN:fi:uta-201411282355

Author(s):

Heikkinen, Anna; Kujala, Johanna; Lehtimäki, Hanna

Title: Managing stakeholder dialogue: the case of Botnia in Uruguay

Year: 2013

Journal Title:

South Asian Journal of Business and Management Cases

Vol and number:

$2: 1$

Pages:

25-37

ISSN:

2321-0303

Discipline:

Business and management

School /Other Unit:

School of Management

Item Type:

Journal Article

Language:

en

DOI:

http://dx.doi.org/10.1177/2277977913480594

URN:

URN:NBN:fi:uta-201411282355

Subject:

sidosryhmäsuhteet; sidosryhmävuoropuhelu;

monikansallinen liiketoiminta; ulkomainen investointi;

konflikti

All material supplied via TamPub is protected by copyright and other intellectual property rights, and duplication or sale of all part of any of the repository collections is not permitted, except that material may be duplicated by you for your research use or educational purposes in electronic or print form. You must obtain permission for any other use. Electronic or print copies may not be offered, whether for sale or otherwise to anyone who is not an authorized user. 


\title{
Managing Stakeholder Dialogue: The Case of Botnia in
}

\section{Uruguay}

Anna Heikkinen, Johanna Kujala, and Hanna Lehtimäki

\begin{abstract}
Stakeholder dialogue is an effective way for a company to enhance its sensitivity to the operational environment and to increase stakeholders' understandings of the dilemmas facing the company. An open and transparent dialogue process can create fertile ground for solving tensions in stakeholder relations. However, the process is not always straightforward. This article presents a case where a Finnish forest industry company's decision to build a pulp mill in Uruguay raised both opposing and supporting views among the local interest groups. The company faced the challenge of how to engage with the hostile, opposing groups in order to ensure their operations in Uruguay. By engaging in this case, students will deepen their understanding of the multitude of stakeholder interests and learn to facilitate a dialogue that seeks to find solutions and avoid conflict in a situation of a stakeholder dispute.
\end{abstract}

\section{Keywords}

Stakeholder relationships, stakeholder dialogue, multinational business, foreign investment, conflict

Disclaimer: This case as developed by Anna Heikkinen, Johanna Kujala, and Hanna Lehtimäki is a revised and updated version of the case titled 'Stakeholder Dialogue: MNE Green Field Investment in Uruguay' as presented by the authors at International Conference on Management Cases (ICMC2012) held on November29-30, 2012 at Bimtech Campus, Greater Noida, India. 
The case has been developed solely as the basis for class discussion, for educational and management development programmes and is not intended to illustrate either effective or ineffective handling of an administrative situation or to present successful or unsuccessful managerial decision making or endorse the views of management in decision making. This study uses secondary data (news reports and information available on the company websites) and the sources have been cited in this case.

\section{Introduction}

The values affecting corporations are increasingly pluralistic, and the political and ethical responsibilities are increasingly pressed upon corporations (Calvano, 2008; Burchell \& Cook, 2008). Multinational enterprises (MNEs) face growing challenges in managing the complexity and intensity of interactions across local and global contexts (Meyer, Mudambi, \& Narula, 2011). Recent research on MNEs questions the established argument that superior performance can be obtained by implementing centralized global strategies, and it further claims that a deep understanding of local context is a necessary requirement for success (Ghemawat, 2007). To sustain a competitive advantage in a complex business environment, firms are required to exercise competitive imagination and to reconcile the perspectives of diverse, dispersed, and even adversarial actors (Hart \& Sharma, 2004).

The stakeholder view can be used to better understand the pluralism of international business. Stakeholder theory defines and explores important stakeholders, and it analyzes the nature of stakeholder relationships, firm-stakeholder interaction processes, and the outcomes of these relationships to organizations and their stakeholders (e.g. Freeman \& Evan, 1990; Freeman, Harrison \& Wicks, 2007; Jones \& Wicks, 1999; Mitchell, Agle \& Wood., 1997; Rowley, 1997; Savage et al., 1991). Research on stakeholders has argued that companies face webs of multiple stakeholder demands rather than individual demands (Rowley, 1997), in which stakeholders may cooperate with other stakeholders in order to influence companies. 
In such a situation, it is important to understand the multitude of stakeholder interests and learn to facilitate a dialogue that seeks to find solutions and avoid conflict.

In recent stakeholder literature, much effort has been placed on understanding stakeholder dialogue (Burchell \& Cook, 2006, 2008; Kaptein \& Van Tulder, 2003; van de Kerkhof, 2006; O’Riordan \& Fairbrass, 2008; Pedersen, 2006). Stakeholder dialogue aims to develop trust between stakeholders and the company. In an open and transparent dialogue process, opinions are exchanged and interests and expectations are discussed so that the company can enhance its sensitivity to the operational environment and increase the stakeholders' understandings of the dilemmas facing the company (Kaptein \& Van Tulder, 2003). Open and trusting relationships can have indirect long-term effects on the ways companies and stakeholders approach joint problems and solve issues (Burchell \& Cook, 2008). Such relationships can also help solve tensions between actors.

Dialogue is not just about informing the stakeholders; rather, it is a mutual process in which all parties engage. Key to successful dialogue is openness and willingness to consider alternative viewpoints (Burchell \& Cook, 2008). In addition, stakeholder dialogue should be planned, and the participants' expectations should be managed so that the dialogue aims are realistic (Burchell \& Cook, 2008). Poor planning can impair relationships if the stakeholders feel ignored or abused, or if meetings turn out to be different from what the participants expected.

\section{The Case}

The case presents a situation where a Finnish forest industry company, Metsä-Botnia Ltd (hereafter Botnia), faced wide-ranging opposition to building a pulp mill in Uruguay and was caught in the crossfire of a heated debate between two countries, Uruguay and Argentina. The situation erupted when Botnia decided to build a major 
pulp mill in the city of Fray Bentos by the Uruguay River in Western Uruguay. Before the investment decision in 2003-2004, Botnia had examined the possibilities for starting pulp production in Uruguay. The company carried out studies assessing the prospective environmental and social impacts of the mill, arranged conferences and meetings for the media, local communities and NGOs, invited Uruguayan reporters and politicians to visit Finland, and held local information dissemination sessions in both Uruguay and Argentina. Despite Botnia's efforts to ensure the project's smooth progress, a disagreement arose regarding the mill's location. The Argentine government and local people on the Argentinian side of the Uruguay River voiced environmental concerns related to the pollution of the river and to the negative impact on tourism. The dispute began as a disagreement between Uruguay and Argentina. Soon, however, it was politicized into an open conflict between the two nations. The conflict also erupted into a public issue that attracted various sets of stakeholders, including civic and environmental organizations, local people, workers, financiers, and the governments of Uruguay, Argentina, and Finland. Figure 1 presents the timeline of the conflict's main events. 


\section{FIGURES}

Figure 1. Timeline of the main events of the case
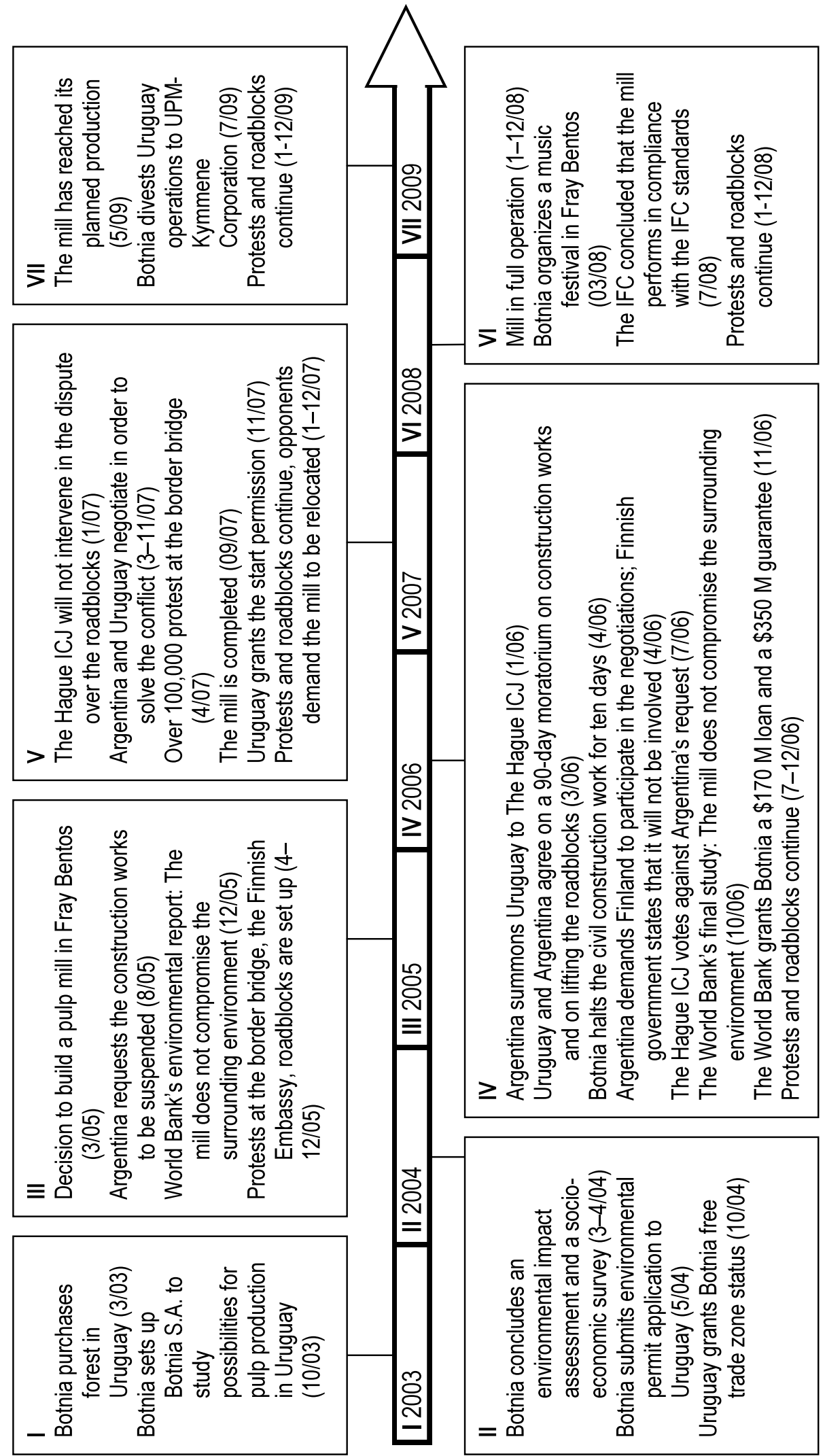


\section{Key Stakeholders}

\section{Botnia}

The Finnish forest industry group Metsä-Botnia Ltd is Europe's second biggest manufacturer of chemical pulp, with an annual production capacity of 2.4 million tonnes of bleached softwood and hardwood pulps. The pulp products are used to manufacture magazine paper, fine paper, board and tissue. The company was founded in 1973 and owned four pulp mills located in Finland and one sawmill in Russia before their investment in Uruguay. In 2004, the company had approximately 2,000 employees and a turnover of over EUR 1 billion.

In 2003, Botnia set up a company called Botnia S.A. to investigate prospects for starting pulp production in Uruguay and to later implement the pulp mill project. In 2003, the cost of the investment was estimated USD 1.1 billion (EUR 830 million), and the planned annual capacity of the mill was 1 million tonnes of bleached eucalyptus pulp. In addition, their other Uruguay-based subsidiary, Compaña Forestal Oriental S.A. (FOSA), specializes in eucalyptus plantations. In 2005 , the company owned 90,000 hectares of land and forest areas in Uruguay, of which 40 per cent was preserved as pastures and sanctuaries. FOSA's plantations have received the FSC (Forest Stewardship Council) certification.

\section{Uruguayan Government}

The Uruguayan government welcomed the pulp mill investment, as it was estimated to boost the country's gross national product (GNP) by more than USD 200 million a year, accounting for 1.6 per cent of Uruguay's GNP. The mill was estimated to employ about 300 people and to provide direct or indirect jobs for approximately 
8,000 people. Uruguay granted the mill free-trade-zone status in 2004 for 30 years, during which time the company would not pay taxes to the government. Uruguay and Argentina had signed a bilateral agreement, the 1975 Uruguay River Statute, to protect the use of the Uruguay River. The statute required both parties to agree on any issue concerning the river.

\section{Argentine Government}

The Argentine government opposed the mill, claiming that it would cause environmental damage. Further, it claimed that Uruguay had violated the Uruguay River Statute by allowing Botnia to build the mill by the river without asking Argentina's permission.

\section{The Argentinian Citizens Environmental Assembly of Gualeguaychú (CEAG)}

The city of Gualeguaychú lies on the Argentinian side of the Uruguay River, 50 kilometres from the pulp mill. In 2002, citizens of Gualeguaychú founded an environmental organization, The Argentinian Citizens Environmental Assembly of Gualeguaychú (CEAG), to oppose the plans of the Spanish Grupo Empresarial Ence SA (Ence) to build a pulp mill in Fray Bentos, Uruguay. The members of CEAG travelled to Spain where they witnessed the environmental problems of a local pulp mill. When Botnia announced its plans to build a mill in Fray Bentos, the group was prepared to take action. The members organized massive demonstrations against the pulp mill, claiming that the mill would, among other things, pollute the river, contaminate the soil, and ruin the tourism business in the area. In 2006, Ence decided to build the mill in another location in Uruguay, but the opposition for the 
mills was already in full speed. CEAG gained the open support of many Argentine politicians; some of them even participated in the demonstrations.

\section{Events of the Pulp Mill Project}

\section{3-2004: Background of the Investment Decision}

In Finland, the forest industry has traditionally provided steady employment, especially in rural areas, and entire towns have grown to surround pulp and paper mills. During the past decade, the industry has been struggling with declining sales and increasing production costs. The remedy has been to divest operations in Finland and to look for new opportunities in Latin America and Asia. As a result, the industry has faced criticism in Finland due to closures of entire mills and the resulting massive lay-offs.

Botnia has a long history, growing from a single mill company to a significant and a well-known multinational company. Over the years, Botnia has invested in environmental protection. The company has developed the protection of waterways, and, at the end of 1980s, it decided to develop a chlorine free bleaching process, which replaced gaseous chlorine with oxygen compounds.

Prior to the investment decision, from 2003 to 2004 Botnia had completed studies on initiating pulp production in Uruguay and on the environmental and social impacts of the proposed mill. The studies included interviews with local people in Uruguay who were mostly in favour of the project for the economic benefits and the prospective jobs, although they were also concerned about the local environment.

The results of the environmental impact assessment stated that the pulp mill would have little noticeable effect on the immediate environment or on the quality of water in the Uruguay River. Moreover, it would not affect the health of fish, algae or people. 
The only noticeable changes would be related to the landscape, occasional odour problems, and increased traffic during the construction and start-up phases. The results of the socio-economic survey showed that the pulp mill project would have a substantial impact on the Uruguayan economy and would directly or indirectly provide jobs for about 8,000 people. The company engaged with and informed local stakeholders and the media, and the project received considerable publicity both in Finland and in Uruguay.

In February 2005, Uruguay's environmental authority granted an environmental permit for the pulp mill project. In March 2005, the investment decision was finalized. The project was funded through capital investments and external loans. The World Bank provided Botnia a EUR 55 million credit and securities for, inter alia, political risks.

A number of reasons favoured the choice of Uruguay, and specifically the city of Fray Bentos, to be the site for the pulp mill. The company's customers required eucalyptus pulp to maintain and to improve the quality and competitiveness of their fine paper products. The fast-growing eucalyptus is affordable in Uruguay, where pasturelands have been turned into eucalyptus plantations and trees have been planted since the 1980s with the support of the World Bank and the Uruguayan government. The city of Fray Bentos is closely situated to large eucalyptus plantations. Annually, the mill will use 3.5 million cubic metres of wood. The majority of this wood will be supplied from FOSA's plantations and the remaining 40 per cent of the wood will be purchased through long-term contracts from private forest owners, funds, foundations or cooperatives. In addition, Uruguay's well-developed legislation, political stability and clear land ownership rights influenced the investment decision. 
When the project was kicked off, Botnia expected the pulp mill to start operating in autumn 2007 and estimated that the total cost of the project would be USD 1.1 billion. Thus, the pulp mill project was going to be the biggest Finnish private sector foreign industrial investment and the biggest industrial investment in the history of Uruguay.

2005: Project Launch Facing Headwind,Construction Work Begins, First Signs of Opposition

The construction work began in September 2005. The citizens of Fray Bentos welcomed the prospective jobs:

'People need jobs and it doesn't matter if the mill pollutes a bit,' stated Maria Acuna. 'My only fear is that the builders bring machinery and employees from other parts of Uruguay, and no work is available for local people.' Maria Acuna would welcome a job at the mill, but she was not sure of her qualifications. 'I don't know if I would be qualified. I don't have any vocational training.'

According to Luis Gutierrez, who worked as a scavenger, it was 'perfect' that a massive mill was being built uptown: 'People do a lot of odd jobs here, and permanent jobs are welcome.' (livonen, 2005a)

Environmental and civic organizations such as Greenpeace and the local CEAG opposed the project from the day one. Greenpeace demonstrated at the mill, claiming that the construction was illegal under the conditions of the Uruguay River Statute. They criticized the company for polluting the environment and demanded that the mill be relocated to an area where it would not harm local livelihoods. Similarly, Argentines feared that the mill would pollute the river, foul the area, and ruin the tourism business. The first anti-pulp mill protests on the border bridge were already organized in spring 2005. In autumn, a massive protest brought together 
15,000 people to oppose the pulp mill. The protest was called Grito Blanco (White Cry) because of the participating students' white uniforms, and it was one of the first events to receive international media attention. The protestors also set up roadblocks on the border bridge. The first protest at the Finnish Embassy in Buenos Aires, Argentina was organized in December 2005. These protestors sought to appeal to the decision-makers emotions:

'We do not want death upon the Uruguay River. We demand the mills to be shut down immediately, for they will pollute our children's future. This is a protest for peace, environment and life,'states Gualeguaychúan Alejandro Gahan. (Pohjola, 2005).

The Argentine protestors claimed that Botnia would use technology that was prohibited in Europe. The company felt that their efforts to provide information were unfruitful:

Botnia has not been able to influence Argentines' opinions even though the mill's environmental impact assessment is a public document. 'I doubt that anyone in Argentina has read it or that the general public has the faintest idea of this industry. And if they do, it is an image of the old industry,' Varis [Botnia's CEO] states. (livonen, 2005b)

\section{Quarrel Between Argentina and Uruguay}

The governments of Argentina and Uruguay disagreed about the pulp mill. Argentina criticized the environmental impact assessment conducted by Botnia and demanded the construction work to be suspended until a new environmental assessment was concluded. In addition, Argentina claimed that the Uruguayan government had not asked its permission to build the mill on the border river and had thus violated the Uruguay River Statute. When Argentina demanded the construction work of the mill to be suspended, Uruguay was stuck between a rock and a hard place: the continuation of the construction and operation of the mill would bring significant 
economic benefits to the area and the country; however, Uruguay did not want to risk their long-standing relations with Argentina or harm the economy, as the roadblocks were inflicting significant losses - especially on their tourism industry.

\section{6: The Storm Is Rising,Demands to Suspend the Construction}

During 2006, the quarrel between Uruguay and Argentina turned into a raging storm affecting various stakeholders. In January 2006, Argentina declared that it would take the case to The Hague International Court of Justice (ICJ), demanding the project to be suspended on the grounds that Uruguay violated the Uruguay River Statute. The court proceedings were closely followed by the international press and turned the conflict into an internationally notable issue. Botnia's CEO commented on the court proceedings:

'Taking the dispute to The Hague was no surprise,' says Metsä-Botnia's CEO Erkki Varis. He emphasizes that Metsä-Botnia is not a party in the court case involving Argentina and Uruguay.

Varis assesses that it is not very likely that the court should demand the construction work to be suspended.

According to Varis the recent developments of the dispute may even ease the tense situation. 'Acute quarrelling may decrease. Argentina has now removed the roadblocks because a process like this makes it difficult to perform illegal operations,' Varis states. (Width, 2006)

In March 2006, the presidents of Uruguay and Argentina agreed to appeal for a 90day moratorium on construction work until another new, independent environmental impact study had taken place. They also agreed that the roadblocks damaging the 
Uruguayan economy and free movement of people and goods would be lifted. The employees and residents of Fray Bentos opposed the suspension and organized a demonstration in favour of the mill.

In April, Botnia halted the works for ten days instead of the 90 days required by the presidents:

With the purpose of contributing to opening a space for dialogue between the republics of Uruguay and Argentina and answering the requests made by Presidents Tabaré Vazquez and Nestor Kirchner, Botnia is willing to suspend, for a maximum period of 90 days, the installation of the pulp mill that is being built in the city of Fray Bentos, Department of Rio Negro, in Uruguay.

The Uruguayan government has informed that in this period of time both countries will study the environmental impact that the mills could generate in the region. To facilitate this, the company will give all the information needed in order to clarify the doubts that might exist and to ensure the correct conditions of operation and control of the pulp mills. (Oy Metsä-Botnia $A b, 2006)$

The presidents had already agreed that they would negotiate during the moratorium, but as Botnia refused to cooperate, relations were broken off. In July 2006, The Hague ICJ ruled that there were no grounds for imposing suspension on the construction works.

\section{Demands for the Finnish Government to Intervene}

In spring 2006, the Argentine government requested the Finnish government to help to resolve the conflict. The government, however, responded that they would not intervene. The Finnish Minister of Foreign Trade and Development stated that 
Uruguay, Argentina and Botnia, as a private company, should resolve the conflict.

Demonstrations were organized outside the Finnish Embassy in Buenos Aires, and the demonstrators called for Finland to bear its responsibility. In August 2006, the representatives of civic and environmental organizations visited Finland and delivered a petition of over 40,000 signatures from Gualeguaychú to the Finnish Minister of Foreign Trade and Development. The Minister reiterated that the Finnish government was not a party to the conflict.

\section{Influencing the IFC's Decision-making Process}

The World Bank Group's International Finance Corporation (IFC) had started an independent cumulative impact study of the mill in 2005 , and the findings stated that the mill would not harm the environment. Argentina declared that the report was preliminary and inadequate, and the IFC embarked on another assessment. In response, Botnia publicly accused Argentina of delaying the financing decision. The members of CEAG endeavoured to influence the financing banks through demonstrations and roadblocks, as well as by writing letters to the banks.

The final version of the environmental study was released in October 2006, and it stated that the pulp mill would not harm the environment, and that it would benefit the Uruguayan economy. In November, Botnia announced that it would utilize its knowhow to improve the quality of the water of the Uruguay River. The company stated that it would work together with relevant authorities and companies in Uruguay to enable the treatment of domestic sewage from the city of Fray Bentos in the mill's effluent treatment plan.

The pulp resistance movement gained momentum towards the end of 2006. The Argentine newspapers fuelled the opposition, and Uruguay prepared to prevent 
terrorism at the mill even with military forces. CEAG had the support of Argentine society, companies and politicians; President Kirchner had even appointed the CEAG leader as the Argentine Minister of the Environment.

In November 2006, despite continuing criticism from Argentina, the IFC and MIGA (Multilateral Investment Guarantee Agency) granted a USD 170 million loan and a USD 350 million guarantee for the project. The Argentine president responded by emphasizing that they would not prevent the roadblocks, which compelled Uruguay to take the case to The Hague ICJ. In December, the installation began at the mill and the number of workers peaked with 4,000 people.

\section{7: Start-up in the Midst of Continuing Controversy}

In 2007, the annual carnival in Gualeguaychú was opened with dancers dressed in colourful ostrich feather costumes and carrying a poster with an anti-Botnia slogan. The Argentines could not understand why the mill was built by the beautiful river and near the border bridge, where it was constantly in sight. The citizens stated that they did not oppose the industry in general, only the location of the mill.

In spring 2007, Argentina and Uruguay tried to resolve the conflict in negotiations led by the King of Spain. The Finnish government and Botnia were expected to participate, but as they refused, the negotiations ended unsuccessfully. At the same time, CEAG demanded that the construction work be suspended in order to maintain peace in the society, and stated that if the mill began its operations, CEAG would regard it as a declaration of war. A massive demonstration of over 100,000 participants was organized in April 2007. The opposing stakeholders continued to set up roadblocks; some of them had been there for over four months. The Argentine police had even set up an office at the roadblock, but they did not try to remove it. 
In October, CEAG set up a fake website that they claimed was Botnia's official website in Argentina. Botnia demanded the website to be shut down and sent lawyers after the group:

'It is an illegal act, because our logo cannot be used in such circumstances,' stated MetsäBotnia's CEO Varis.

Varis characterizes the activists' website as childish nonsense. 'I doubt that anyone takes them too seriously.' (livonen, 2007)

The construction and installation were completed by September 2007. The mill started its operations November 9, 2007. See Appendix 1 for the project's fact sheet.

\section{8-2009: Production in Full Speed}

In early 2008, the mill was in full operation, and deliveries to customers in Europe and China commenced. In March, Botnia organized a music festival in Fray Bentos with the local authorities, and in April 2008, Botnia launched an educational, travelling exhibition on pulp production process in Fray Bentos. The activists continued their protests, insisting that they would not lift the roadblocks unless the mill was relocated. In July 2008, the IFC released the first environmental monitoring report of the pulp mill. According to the report, the mill was performing in compliance with the air and water quality standards required by the IFC.

In May 2009, Botnia announced that the mill had reached its planned production and had produced to date more than $1,300,000$ tonnes of pulp. In July 2009 , Botnia announced the divestment of the mill to another Finnish forest industry company and a new focus on being the premier supplier of Finnish pulp through its Finland-based mills. 
The protests and roadblocks continued through 2008 and 2009. Some of the protestors were disappointed that the roadblocks had no effect on the mill, while others feared that the removal of the roadblocks would result in the opposition fading from the public eye.

\section{Conclusions}

This case presents a situation where a Finnish forest industry company's investment project in Uruguay raised both supporting and opposing views among local stakeholders. From a stakeholder dialogue point of view, this case raises an intriguing issue: the company sought to ensure that all stakeholders were considered during the decision-making process and tried to inform them during the project, and yet it faced fierce opposition that hampered the project.

Interactive, or multi-voiced, dialogue is seen as a more efficient and satisfactory means of communicating than ad hoc or one-way communication (Crane \& Livesey, 2003). In a conflict situation, a company could increase stakeholder involvement, provide stakeholders with more information on its strategic plans and operations, and engage in more communication with different stakeholders. Key to such communication is the ability to identify with stakeholders and seek an understanding and appreciation of their concerns.

We conclude that stakeholder dialogue is an aspect of relationship management and a process where the firm and its stakeholders learn to live with multiple realities. This case shows how a dispute of this magnitude involves several factors, such as a 
company's investment policy and strategy, local and global politics. The same situation can be approached both as a question of foreign investment that creates work and wealth and as a political question in which two countries dispute with each other and seek international support for their views. Each construction of the situation builds and legitimizes the identities of different stakeholders, and, thus, also serves to legitimize the interests and actions of each stakeholder. The challenge for both academic researchers and business managers lies in developing tools and methods for stakeholder dialogue that can help the company to understand the multi-voiced nature of this dialogue and lead it to take responsibility in the process.

\section{Questions}

1. In the case introduction, Botnia, the Uruguayan government, the Argentine government and the environmental organization CEAG are introduced as key stakeholders. What interests in the case do these stakeholders have, and how do these interests evolve throughout the conflict?

2. What other stakeholders are involved in the case? What are their interests and how do those interests change during the conflict?

3. What kinds of arguments do the stakeholders opposing the pulp mill project present to support their view? How about the defensive stakeholders? What hopes, fears and demands do these stakeholders have as groups or individuals, and why?

4. What kinds of solutions could there be to solve the conflict? Is there any room for a compromise? How could Botnia find a way out? What other possibilities are there? 
5. Would it be possible to build a stakeholder dialogue between the company and the stakeholders in this case? How would you do it?

\section{Acknowledgements}

The authors would like to thank the participants of the International Conference on Management Cases 2012 held on November 29-30 at Birla Institute of Management Technology, Greater Noida, India,for their constructive comments on previous versions of this paper. The financial support of Foundation for Economic Education, Finland, is gratefully acknowledged.

\section{References}

Burchell, J. \& Cook, J. (2006). It's good to talk? Examining attitudes towards corporate social responsibility dialogue and engagement processes. Business Ethics: A European Review, 15(2), 154-170.

Burchell, J. \& Cook, J. (2008). Stakeholder dialogue and organisational learning: changing relationships between companies and NGOs. Business Ethics: $A$ European Review, 17(1), 35-46.

Calvano, L. (2008). Multinational Corporations and Local Communities: A Critical Analysis of Conflict. Journal of Business Ethics, 82(4), 793-805.

Crane, A. \& Livesey, S. (2003). Are You Talking to Me? Stakeholder Communication and the Risks and Rewards of Dialogue. In J. Andriof, S. Waddock, B. Husted \& S. Sutherland Rahman (Eds.), Unfolding Stakeholder Thinking 2: Relationships, Communication, Reporting and Performance, 39-52. Sheffield: Greenleaf Publishing Limited.

Freeman, R.E. \& Evan, W.M. (1990). Corporate Governance: A Stakeholder Interpretation. The Journal of Behavioral Economics, 19(4), 337-359. 
Freeman, R.E., Harrison, J. \& Wicks, A. (2007). Managing for Stakeholders. Survival, Reputation, and Success. London: Yale University Press.

Ghemawat, P. (2007). Redefining Global Strategy. Boston, MA: Harvard Business School Press.

Hart, S. \& Sharma, S. (2004). Engaging fringe stakeholders for competitive imagination. Academy of Management Executive, 18(1), 7-18.

livonen, J. (2005a, May 22). Fray Bentosin pikkukaupunki toivottaa sellutehtaan työpaikat tervetulleeksi. [The small town of Fray Bentos welcomes pulp mill jobs]. Helsingin Sanomat. Retrieved 6 March 2012, from http://www.hs.fi

livonen, J. (2005b, August 11). Argentiina vaatii Botnian selluhankkeen keskeyttämistä. [Argentina demands Botnia's pulp mill project to be suspended]. Helsingin Sanomat. Retrieved 6 March 2012, from http://www.hs.fi

livonen, J. (2007, October 6). Argentiinalainen ympäristöjärjestö väärensi Botnian nettisivut. [Argentine environmental organization forged Botnia's website]. Helsingin Sanomat. Retrieved 6 March 2012, from http://www.hs.fi

Jones, T.M. \& Wicks, A.C. (1999). Convergent stakeholder theory. Academy of Management Review, 24(2), 206-221.

Kaptein, M. \& Van Tulder, R. (2003). Toward Effective Stakeholder Dialogue. Business and Society Review, 108(2), 203-224.

van de Kerkhof, M. (2006). Making a difference: On the constraints of consensus building and the relevance of deliberation in stakeholder dialogues. Policy Sciences, 39(3), 279-299. 
Meyer, K.E., Mudambi, R. \& Narula, R. (2011). Multinational Enterprises and Local Contexts: The Opportunities and Challenges of Multiple Embeddedness. Journal of Management Studies, 48(2), 235-252.

Mitchell, R.K., Agle, B.R. \& Wood, D.J. (1997). Toward a Theory of Stakeholder Identification and Salience: Defining the Principle of Who and what really Counts. Academy of Management Review, 22(4), 853-886.

O'Riordan, L. \& Fairbrass, J. (2008). Corporate Social Responsibility (CSR): Models and Theories in Stakeholder Dialogue. Journal of Business Ethics, 83, 745758.

Pedersen, E.R. (2006). Making Corporate Social Responsibility (CSR) Operable: How Companies Translate Stakeholder Dialogue into Practice. Business and Society Review, 111(2), 137-163.

Pohjola, J. (2005, December 8). Botnian sellutehtaan vastustajat osoittivat mieltään Argentiinassa. [The opposers of Botnia's pulp mill demonstrated in Argentina]. Helsingin Sanomat. Retrieved 6 March 2012, from http://www.hs.fi

Oy Metsä-Botnia Ab. (2006). Botnia willing to suspend installation [Press release]. Retrieved 28 October 2011, from http://www.botnia.fi

Oy Metsä-Botnia Ab. (2007). Botnia's pulp mill project in Uruguay [Press release]. Retrieved 28 October 2011, from http://www.botnia.fi

Rowley, T.J. (1997). Moving Beyond Dyadic Ties: a Network Theory of Stakeholder Influences. Academy of Management Review, 22(4), 887-910.

Savage, G. T., Nix, T. W., Whitehead, C. J. \& Blair, J. D. (1991). Strategies for assessing and managing organizational stakeholders. Academy of Management Executive, 5(2), 61-75. 
Width, T. (2006, May 6). Argentiinan valtio vei sellutehdaskiistan Haagiin. [The Argentine government took the pulp mill dispute to The Hague]. Helsingin Sanomat. Retrieved 6 March 2012, from http://www.hs.fi

\section{Bio briefs}

Anna Heikkinen is a doctoral student at the University of Tampere, School Of Management, Finland. Her research interests include stakeholder theory, corporate responsibility and environmental management. Anna is recipient of BIMTECH-Stough Young Scholar Award for 'Best Paper' contributed at International Conference on Management Cases(ICMC2012).She is accessible at email: Anna.L.Heikkinen@uta.fi

Johanna Kujala is Senior Research Fellow, Adjunct Professor and Director of the RESPMAN (Responsible Management) Research Group at the University of Tampere, School of Management. Dr. Johanna Kujala can be approached at email: Johanna.Kujala@uta.fi

Hanna Lehtimäki is a professor at Kuopio Campus, University of Eastern Finland, Kuopio, Finland. Her research interests include strategic management, networks and social capital, and constructionist research methodology. Dr. Hanna Lehtimäki can be approached at email: Hanna.Lehtimaki@uef.fi 


\section{Appendix 1. Project fact sheet}

Botnia's pulp mill project in Uruguay

General

- Location: City of Fray Bentos, Uruguay

- Cost estimate: USD 1.2 billion

- Capacity: 1 million tons of ECF bleached (elemental chlorine free) eucalyptus pulp/year

- Investment decision made in March 2005

- Start-up in November 2007

Financing

- Ca. 60 per cent as equity from Botnia and other stakeholders

- Ca. 40 per cent dept financing through World Bank, export credit agencies, NIB and commercial banks

Socioeconomic impacts in Uruguay

- GDP estimated to increase by 1.6 per cent

- Employment effect during construction period: max. 5.300 at the site

- Employment effect during pulp mill operations: 3.000 direct new jobs, 5.000 indirect new jobs

Largest ever construction project in Uruguay

- Total man-hours during construction: 15.000 .000

- Total cargo transported: 58.000 tons

- 64 participating companies

Environmental impacts as defined in CIS (Ecometrix) and Experts Report (Hathfield consultants)

- No biological impacts on the Uruguay River

- Occasional and minor local odour problems

- No significant noise problems

- Main impacts on traffic and landscape

- No impacts on the present livelihoods in the area (agriculture, tourism)

Machinery

- Fibreline: ECF bleaching with hexenuronic acid removal. Lowest bleaching chemical consumption in the reference mills around the world.

- Energy self-sufficiency $165 \%$

Source: Oy Metsä-Botnia Ab, 2007 